\title{
Effectiveness of Wattle Tree (Acacia Pynantha) Bio Mordant and Blackjack (Bidens Pilosa) Dye on Textiles
}

\author{
Senelisile Moyo, Bukisile P Makhanya* and Viggie G Maseko \\ Department of Textile and Apparel Design, University of Eswatini, Eswatini
}

Submission: July 14, 2020; Published: July 29, 2020

*Corresponding author: Bukisile P Makhanya, Department of Textile and Apparel Design, University of Eswatini, P. O. Luyengo, M205, Eswatini

Keywords: Wattle tree; Bio mordant; Blackjack; Dye-extraction; Dye-uptake; Dye-fixation; Colorfastness

\section{Introduction}

World-wide there is a growing consciousness for use of eco-friendly products in daily life that has generated renewed consumer interest towards the use of textiles dyed with ecofriendly natural dyes [1]. Natural colorants are emerging globally since they are safer and more environment-friendly and thus the application of natural dyes is considered as a better alternative to synthetic dyes [2].

According to Uddin (2015), the textile dyeing industry utilizes excessive amount of textile chemicals to meet required coloration for the global textile consumption [3]. This is due to cheaper prices, wider ranges of bright shades, and considerably improved fastness properties in comparison to natural dyes. Unfortunately, the production of textile chemicals is dependent on petrochemical sources, and some of these chemicals contain carcinogenic amines. The application of such chemicals causes serious health hazards and negatively influences the eco-balance in nature. The use of synthetic dyes has decreased and consequently, there is an exploration of using natural ingredients to make wet processing environmentally friendly.

According to Masarirambi, Zwane, Surana, Kunene, Moyo et al. (2019) The kingdom of Eswatini (Swaziland) is rich in diverse color pigment producing indigenous plants. Plants are potential sources of dye because of their easy availability and abundance in nature and they are among the promising options for developing a greener textile industry [4]. One of the difficulties is, the dyes are mostly non-substantive and need to be applied on textile materials with the help of mordants. Synthetic mordants are then used to fix the dyes. Meanwhile, these synthetic mordants are also not environmentally friendly, hence the process cannot be considered as 'green dyeing' wholly. The objectives of the study were to extract dye from black jack Bidens pilosa and bio mordant from barks of wattle Acacia pynantha tree, determine the dye exhaustion and dye fixation and also evaluating the colorfastness to washing and crocking/rubbing (dry and wet) of $100 \%$ cotton substrate.

\section{Methods}

Blackjack leaves and barks of wattle were ground into powder form after shade drying for two months. Using the aqueous method, the plant source was extracted at $10 \mathrm{~g} / 1000 \mathrm{ml}$ distilled water for 60 minutes after soaking overnight, the content was then cooled down at room temperature and filtered to a clear solution [3]. The pre and post mordanting methods were used. The samples were treated with different concentration percentages (of liquor ratio) at $10 \%, 30 \%$, and $50 \%$ of the wattle extract. Alum was also used as a synthetic mordant for comparison. For each sample, the Material to liquor ratio was $1: 20$, each gram of the sample weight $20 \mathrm{ml}$ of liquor was used. Color fastness to washing test were conducted according to the standard test of AATCC test method 61 and for the crocking test, AATCC 116 method 8 was used. Grey scale and a Chromatic Transference Chart and the multi-fiber strip (for level of staining) were used for evaluating color fastness.

\section{Results and Discussion}

The results have shown that for wash fastness, the premordanting method gives poor results and post mordanting method has fairly good results and for fastness to rubbing it had excellent results. The level of staining when washed together 
with multi-fiber strip shows that worsted wool was stained, and bleached cotton and the other fibers showed excellent resistance to staining results at $4 / 5$ to 5 . The results also show that the premordanting method produces poor results ranging between 2 to $3 / 4$ whilst post-mordanting had the best results ranging between 4 and 5 in colorfastness to washing and good to excellent results in colorfastness to crocking/rubbing for both wet and dry method. Post-mordanting also showed maximum dye exhaustion. The concentration was low because some of the coloring matter was insoluble in water and was therefore not extracted even though they were soaked. The post mordanting method had a higher percentage of dye up take than pre mordanting. In dye fixation, the pre mordanting method had poor results and post mordanting method had fairly good results with regards to wash fastness properties. The level of staining in the multi-fiber strip was good in worsted wool and bleached cotton and the other fibers had excellent results. Both mordanting methods produced excellent results for colorfastness to crocking (dry) method and fairly good results in wet method.

\section{Conclusion and Recommendations}

It can be concluded that a yellow natural dye can be efficiently extracted from Bidens pilosa leaves. The extracted dye could be successfully attached to cotton yarn with both bio and chemical (alum) mordants. However, the bio mordant showed better result than alum with regards to wash and rub fastness properties. This is an indication that bio mordants and natural dyes can successfully be used as replacement for their synthetic counterparts. Future research can be conducted to determine color yield and an investigation of how exhaustion can be enhanced in the aqueous extraction method that resulted in low absorbance in the current study. It is also recommended that further research may assess the real potential and availability of natural dye and bio-substance yielding resources in Eswatini to contribute to the textile processing knowledge base as well as for propagation of species on commercial scale.

\section{References}

1. Ismal ÖE, Ylldırım L (2012) Almond shell as a natural colorant. Indian Journal of Fibre \& Textile Research 37(4): 358-363.

2. Swamy VN, Gowda KN, Sudhakar R (2014) Dyeing properties of natural dye Syzygium cuminii on silk. Journal of the Institution of Engineers (India) Series E 95(1): 11-17.

3. Uddin MG (2015) Extraction of eco-friendly natural dyes from mango leaves and their application on silk fabric. Textile and Clothing Sustainability 1(1):1- 7 .

4. Masarirambi MT, Zwane PE, Surana N, Kunene EN, Moyo S, et al. (2019) Indegenous dye plants of the kingdom of Eswatini, traditional uses and new prospects. Advancement in Medicinal Plant Research 7(1): 8-14.

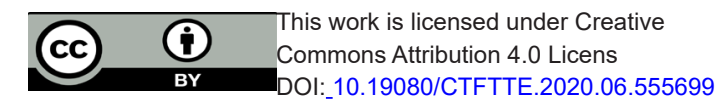

\section{Your next submission with Juniper Publishers} will reach you the below assets

- Quality Editorial service

- Swift Peer Review

- Reprints availability

- E-prints Service

- Manuscript Podcast for convenient understanding

- Global attainment for your research

- Manuscript accessibility in different formats

( Pdf, E-pub, Full Text, Audio)

- Unceasing customer service

Track the below URL for one-step submission https://juniperpublishers.com/online-submission.php 